\title{
Comparison of the Respiratory Responses to External Resistive Loading and Bronchoconstriction
}

\author{
Steven G. Kelsen, Thomas F. Prestel, Neil S. Cherniack, Edward H. Chester, \\ and E. Chandler Deal, Jr., Pulmonary Division, Department of Medicine, \\ Case Western Reserve University, School of Medicine, Cleveland, Ohio 44106
}

A B S T RAC T The effects of resistive loads applied at the mouth were compared to the effects of bronchospasm on ventilation, respiratory muscle force (occlusion pressure), and respiratory sensations in 6 normal and 11 asthmatic subjects breathing $100 \% \mathrm{O}_{2}$. External resistive loads ranging from 0.65 to $13.33 \mathrm{~cm} \mathrm{H}_{2} \mathrm{O}$ /liter per $\mathrm{s}$ were applied during both inspiration and expiration. Bronchospasm was induced by inhalation of aerosolized methacholine. Bronchospasm increased ventilation, inspiratory airflow, respiratory rate, and lowered $\mathrm{PA}_{\mathrm{CO}_{2}}$. External resistive loading, on the other hand, reduced respiratory rate and inspiratory flow, but left ventilation and $\mathrm{PA}_{\mathrm{CO}_{2}}$ unaltered. FRC increased to a greater extent with bronchospasm than external flow resistive loads. With both bronchospasm and external loading, occlusion pressure increased in proportion to the rise in resistance to airflow. However, the change in occlusion pressure produced by a given change in resistance and the absolute level of occlusion pressure at comparable levels of airway resistance were greater during bronchospasm than during external loading. These differences in occlusion pressure responses to the two forms of obstruction were not explained by differences in chemical drive or respiratory muscle mechanical advantage. Although the subjects' perception of the effort involved in breathing was heightened during both forms of obstruction to airflow, at any given level of resistance the sense of effort was greater with bronchospasm than external loading. Inputs from mechanoreceptors in the lungs (e.g., irritant receptors) and/or greater stimulation of chest wall mechanoreceptors as a result of increases in lung elastance may explain the differing responses elicited by the two forms of resistive loading.

\section{INTRODUCTION}

The response to resistive loads applied at the mouth has been used as an indirect test of the respiratory re-

Received for publication 9 September 1980 and in revised form 9 February 1981 . sponses to spontaneously occurring airway obstruction (1-5). In both conscious animals and normal humans, these external loads enhance the drive to the respiratory muscles as assessed from measurements of inspiratory muscle force (occlusion pressure) and electrical activity (diaphragm electromyogram) (1-7). However, external loads may inadequately reproduce many of the effects of airway obstruction on lung mechanics or thoracic mechanoreceptors. In addition, the conscious sensations produced by external loads may be quite dissimilar from those elicited by bronchoconstriction and therefore behavioral responses on breathing may likewise differ.

Recent studies in normal subjects have demonstrated that the occlusion pressure is increased when methacholine is used to induce bronchoconstriction (8). Since previous studies suggest that the functional changes produced by methacholine are similar to those seen in spontaneous asthma, methacholine administration may be a better technique than external loading to study the effects of airway constriction on breathing (9).

In the present study, we compared the effects of methacholine-induced bronchoconstriction and external resistive loading on respiratory drive and timing. In addition, we compared the respiratory sensations elicited by the two forms of airflow obstruction and related these sensations to lung mechanics and respiratory drive. Since the airway response to methacholine is exaggerated in asthmatic subjects, studies were performed in asthmatics as well as normal subjects to allow respiratory responses to be assessed over a wider range of mechanical disturbances than could be produced in normal subjects (10).

\section{METHODS}

Four normal male and two normal female subjects (ages 19-29 yr) with no history of allergy formed the normal group. The asthmatic group consisted of eight men and three women whose mean age was $32 \mathrm{yr}$ (range, 18-52) who fulfilled the American Thoracic Society criteria for the diagnosis of asthma (11). All asthmatics had a history of episodic wheezing and 
dyspnea; 10 were atopic as demonstrated by skin prick tests. All had airway obstruction that was reversible with bronchodilators. All the asthmatics were in a stable respiratory state. Their pulmonary function was characterized in the control state by spirometry, plethysmography, and helium dilution lung volumes.

Forced expiratory volume in $1 s_{1}$ was measured with a 13-liter, water-filled spirometer (Warren E. Collins, Inc., Braintree, Mass.). Functional residual capacity (FRC) ${ }^{1}$ and airway resistance (Raw) were measured in a pressure variable body plethysmograph (12). Because airway resistance is a function of lung volume while specific resistance, the product of resistance times FRC, is not, we assessed the degree of obstruction to airflow from the specific resistance (Sraw). Static lung volumes were measured by the helium dilution method. Bronchodilators were withheld for at least $12 \mathrm{~h}$ before the study.

Obstruction to airflow. External flow resistive loading was produced by placing fine wire mesh screens distal to the mouthpiece of the breathing apparatus. The load was placed so as to interfere with airflow during both inspiration and expiration. The number of screens was varied to produce resistances of $0.65,1.71,5.80,7.93,11.47$, and $13.33 \mathrm{~cm} \mathrm{H}_{2} \mathrm{O} /$ liter per s. Normal subjects were studied with all six loads and the asthmatics with the three highest resistances.

Bronchoconstriction was produced by inhalation of aerosols containing methacholine concentrations of $0.039,0.078,0.156$, $0.313,0.625,1.25,2.5,5.0,10.0,50.0,100,200$, and $400 \mathrm{mg} / \mathrm{ml}$ (13). The asthmatics inhaled first the aerosol with the lowest concentration and then inspired aerosols of increasing concentrations until it was felt by the investigators that further bronchoconstriction was precluded by the patients' clinical status. Each of the normal subjects received in succession aerosols containing the four highest concentrations. A dose of methacholine consisted of five slow vital capacity inhalations of aerosol delivered by a hand-held DeVilbiss 45 nebulizer powered by room air at 6 liters $/ \mathrm{min}$.

FRC and Raw were measured after each dose of methacholine and while subjects breathed on each of the external resistances. During external loading, the resistance of the entire system (i.e., the subject and the external resistance) was measured.

Breathing responses to airway obstruction. Occlusion pressure was determined with the subjects in the sitting position breathing $100 \% \mathrm{O}_{2}$. Measurements were made while subjects breathed through each external resistance and after methacholine was administered. A Douglas valve was connected to the mouthpiece through the inspiratory side of a Hans-Rudolph valve. The valve could be closed during expiration so that the next inspiration was occluded at FRC. Airway pressure was measured with a transducer in communication with the mouthpiece (Validyne MP45-1; $\pm 100 \mathrm{~cm} \mathrm{H}_{2} \mathrm{O}$ ). Occlusion pressure was measured $100 \mathrm{~ms}$ after the onset of inspiration $\left(\mathrm{P}_{100}\right)$. Mean values of at least 12 randomly occluded breaths were calculated at each methacholine dose or external resistance. End tidal $\mathrm{CO}_{2}$ was recorded breath by breath during $\mathrm{P}_{100}$ measurements using a rapidly responding infrared $\mathrm{CO}_{2}$ gas analyzer (Beckman LB-2, Beckman Instruments, Inc., Fullerton, Calif.).

Ventilation and the pattern of breathing were measured in six of the asthmatic subjects at the time of the $P_{100}$ measurements by electrically integrating the flow signal from a pneumotachograph (Fleisch No. 2). The duration of inspira-

${ }^{1}$ Abbreviations used in this paper: FRC, functional residual capacity; $P_{100}$, occlusion pressure $100 \mathrm{~ms}$ after onset of inspiration; Raw, airway resistance; Sraw, specific resistance. tion (TI) and the duration of expiration (TE) were measured from the flow signal.

10 of the asthmatic subjects were asked to quantitate their subjective perception of the effort involved in breathing through the external resistance and during bronchoconstriction. They assigned a number corresponding to the sensation of effort associated with breathing using an arbitrary scale of their own choosing with the only stipulation being that a larger number be used to indicate a greater effort. Numbers were assigned immediately prior to measuring the occlusion pressure and transcribed by the patient on a pad of paper.

Experimental protocol. The experimental procedure during each study was as follows. First, the thoracic gas volume and airway resistance in the control state were measured in the plethysmograph followed by measurement of ventilation and occlusion pressure. External resistances were then added. Subjects were allowed a 10 -min period to adjust to the load; ventilation and occlusion pressure were recorded over a subsequent 5-min period. FRC and resistance were then determined with the subjects still breathing on the resistance. After completing the external loading trials, subjects were administered increasing doses of methacholine to approximate the range of airway resistance achieved with external loading. Successive doses of methacholine were given at $\sim 10$ - to 30 min intervals. Ventilation and occlusion pressure were measured as above when a desired level of airway obstruction was reached. All studies were performed over a 3 - to 5 -h period on the same day.

Comparison of the occlusion pressure responses to both forms of airway obstruction was performed on a second separate occasion in three asthmatic subjects and on a third separate occasion in two subjects.

Linear regression lines and correlation coefficients were determined by the least squares method.

\section{RESULTS}

Base line studies. Pulmonary function was within the predicted normal range for all the normal and 6 of the 11 asthmatic subjects. Sraw was above normal $(<6 \mathrm{~s} /$ $\mathrm{cm} \mathrm{H}_{2} \mathrm{O}$ ) in five asthmatic subjects; and forced expiratory volume, was $<75 \%$ of the predicted normal value in three of the five. FRC and arterial $\mathrm{P}_{\mathrm{O}_{2}}$ and $\mathrm{pH}$ were within normal limits in all asthmatics. $\mathrm{Pa}_{\mathrm{CO} 2}$ was reduced $(<35 \mathrm{~mm} \mathrm{Hg})$ in three asthmatics and normal in the rest. Pulmonary function and blood gas data for the entire asthmatic group are shown in Table I.

Base-line occlusion pressure tended to be greater in the asthmatics $\left(2.3 \pm 0.3 \mathrm{SE} \mathrm{cm} \mathrm{H}_{2} \mathrm{O}\right)$ than in the normal subjects $\left(1.5 \pm 0.2 \mathrm{~cm} \mathrm{H}_{2} \mathrm{O} ; P>0.10\right)$. This appeared to be explained by the relationship between the occlusion pressure and the magnitude of the Sraw (Fig. 1). Thus, for the group as a whole, the greater the Sraw, the greater the base-line occlusion pressure $(r=0.80)$.

Changes in lung function during bronchoconstriction and flow restrictive loading. In all normal and asthmatic subjects, Sraw increased with methacholineinduced bronchoconstriction. Quantitatively greater changes were present in asthmatics than in normals $(P<0.001)$ (Table II). FRC increased during external loading in 12 of the 17 subjects and during bronchospasm in 16 of the 17 (Table II). In every subject, 
TABLE I

Base-line Pulmonary Function and Blood Gas Tensions in Asthmatic Subjects

\begin{tabular}{ccccccc}
\hline & $\begin{array}{c}\text { Forced expiratory } \\
\text { volume }\end{array}$ & FRC & Sraw & pH & Pa $_{\mathrm{CO}_{2}}$ & $\mathrm{~Pa}_{\mathrm{O}_{2}}$ \\
\hline & \% Predicted $^{*}$ & \% Predicted $\mathrm{t}$ & $s \cdot c m \mathrm{H}_{2} \mathrm{O}$ & $\mathrm{U}$ & $\mathrm{mm} \mathrm{Hg}$ \\
Mean $\pm 1 \mathrm{SE}(n=11)$ & $80.7 \pm 5.3$ & $103.5 \pm 6.2$ & $10.3 \pm 1.9$ & $7.42 \pm 0.01$ & $38.4 \pm 1.0$ & $81.2 \pm 2.6$ \\
\hline
\end{tabular}

* Predicted values from reference 35 .

$\$$ Predicted values from reference 36 .

FRC increased to a greater extent during methacholine-induced bronchoconstriction than during external flow resistive loading $(P<0.001)$. Group mean FRC at the highest dose of methacholine was 111 and $151 \%$ of control, respectively, in normal and asthmatic subjects, and 103 and $107 \%$ of control with the severest external resistance.

Ventilation and end tidal $\mathrm{CO}_{2}$. External resistances and bronchoconstriction produced qualitatively different effects on ventilation and the pattern of breathing. Respiratory frequency increased during bronchoconstriction and decreased during external loading in all subjects. During bronchoconstriction, inspiratory time and expiratory time both shortened while during external resistance breathing $\mathrm{TI}$ and $\mathrm{TE}$ lengthened. In five of six asthmatic subjects, inspiratory flow $\left(\mathrm{V}_{\mathrm{T}} / \mathrm{TI}\right)$ was greater with methacholine than with the external loads even though the increase in specific resistance was greater with methacholine (maximum Sraw $38.2 \pm 6.6$ and $33.3 \pm 7.3$ during bronchoconstriction and external resistive loading, respectively). Data for a representative asthmatic subject over a range of resistances are shown in Fig. 2 and for the entire group at the highest levels of resistance in Table III.

The changes in end tidal $\mathrm{CO}_{2}$ produced by external loading and bronchoconstriction varied substantially between subjects. Fig. 3 shows the change in $\mathrm{P}_{\mathrm{CO}_{2}}$ in each subject at the severest level of obstruction pro- duced by external flow resistive loading and bronchoconstriction. In general, end tidal $\mathrm{CO}_{2}$ was unchanged by the external load. In contrast, $\mathrm{P}_{\mathrm{CO}_{2}}$ was significantly decreased during methacholine-induced bronchoconstriction in asthmatic subjects $(P<0.05)$ and tended to decrease in normal subjects $(P<0.10>0.05)$.

Occlusion pressure responses. Increases in resistance, whether produced by bronchoconstriction or external flow resistive loading, were associated with increases in occlusion pressure that appeared to be linearly related to the magnitude of the change in specific resistance ( $r>0.88$ for all trials).

In every subject, the changes in occlusion pressure produced by a given change in resistance (i.e., $\Delta P_{100}$ $\Delta$ Sraw) were greater during methacholine-induced bronchoconstriction than during external loading $(P$ $<0.001)$. Furthermore, at comparable levels of resistance, the absolute magnitude of the occlusion pressure was greater during bronchoconstriction than with the external resistance $(P<0.001)$. The occlusion pressure responses to external resistance and bronchoconstriction in representative asthmatic and normal subjects are shown in Fig. 4. The data for each subject are shown in Figs. 5 and 6 . It should be noted that the greater occlusion pressure responses to bronchoconstriction occurred despite the fact that FRC was larger and $\mathrm{PA}_{\mathrm{CO}_{2}}$ lower during bronchoconstriction than during external resistive loading.

TABLE II

Maximum Change in FRC and Sraw during Flow Resistive Loading and Methacholine-induced Bronchoconstriction

\begin{tabular}{|c|c|c|c|c|}
\hline & \multicolumn{2}{|c|}{ Normals $(n=6)$} & \multicolumn{2}{|c|}{ Asthmatics $(n=11)$} \\
\hline & SRaw & FRC & SRaw & FRC \\
\hline & $s \cdot \mathrm{cm} \mathrm{H}_{2} \mathrm{O}$ & liters & $s \cdot \mathrm{cm} \mathrm{H}_{2} \mathrm{O}$ & liters \\
\hline Control (mean $\pm 1 \mathrm{SE})$ & $3.6 \pm 0.3$ & $3.49 \pm 0.22$ & $10.3 \pm 1.9$ & $3.18 \pm 0.17$ \\
\hline $\begin{array}{l}\text { Methacholine-induced bronchoconstriction } \\
(\text { mean } \pm 1 \mathrm{SE})\end{array}$ & $16.4 \pm 1.5^{*}$ & $3.83 \pm 0.20^{*}+$ & $43.4 \pm 3.5^{*}$ & $4.79 \pm 0.46^{*} \cdot t$ \\
\hline $\begin{array}{l}\text { External resistance }\left(13.33 \mathrm{~cm} \mathrm{H}_{2} \mathrm{O} / \text { liter per s.) }\right. \\
\quad(\text { mean } \pm 1 \mathrm{SE})\end{array}$ & $35.3 \pm 2.7^{*}$ & $3.59 \pm 0.20^{*}$ & $45.2 \pm 4.7^{*}$ & $3.39 \pm 0.26^{*}$ \\
\hline
\end{tabular}

$* P$ value $<0.05$ for the comparison with control.

$\ddagger P$ value $<0.05$ for the comparison with external resistance. 


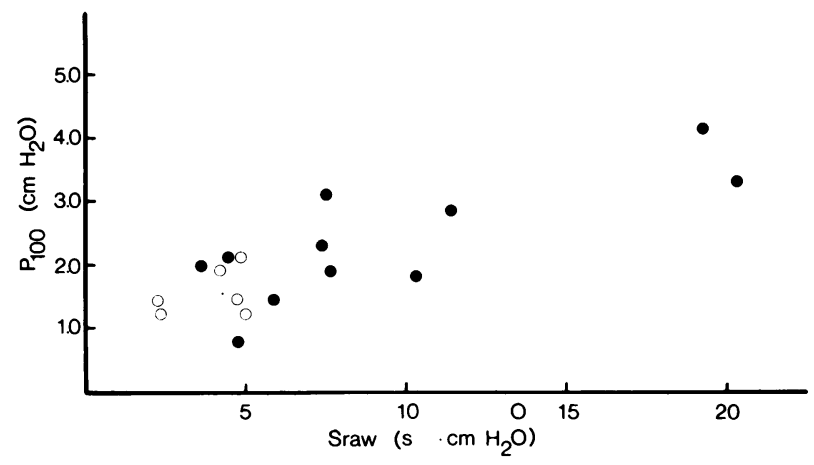

FigURE 1 Relationship of the magnitude of the subject's occlusion pressure $\left(\mathrm{P}_{100}\right)$ under base-line conditions to baseline airway resistance $(\mathrm{Sraw}) . \bigcirc$, indicate normal and $\bullet$, asthmatic subjects $(r=0.80)$.

In three subjects studied on two separate occasions and two subjects studied on three occasions, the change in occlusion pressure produced by either form of resistance $\left(\Delta \mathrm{P}_{100} / \Delta\right.$ Sraw $)$ varied somewhat from study to study. (Within subject coefficients of variation ranged from 9 to $18 \%$ during bronchoconstriction and from 9 to $37 \%$ during external loading.) In each instance, however, the occlusion pressure response to bronchoconstriction was greater than the response to external resistances.

Although the occlusion pressure response $\left(\Delta \mathrm{P}_{100}\right)$ $\Delta$ Sraw) to bronchoconstriction was quantitatively greater than the response elicited by external resistive loading, the two responses correlated significantly $(r$ $=0.77 ; P<0.05)$. That is, those subjects with the greatest occlusion pressure response to methacholineinduced bronchoconstriction had the greatest response to external resistance (Fig. 7).

Perception. The subjects' numerical estimate of the respiratory effort associated with breathing on the external flow resistive loads and during bronchoconstriction appeared to be related to the magnitude of the
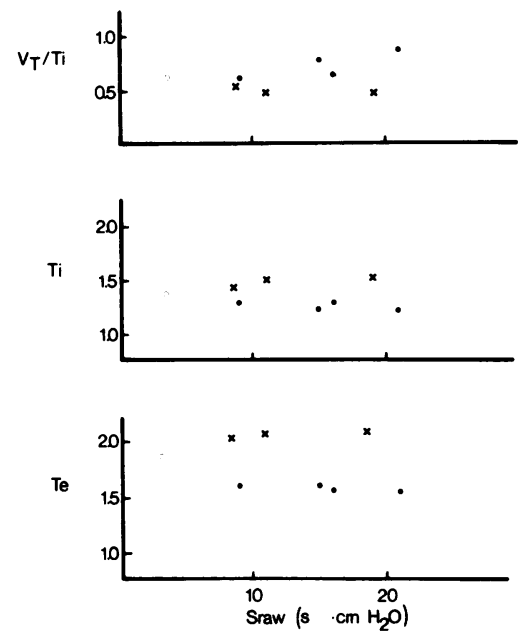

Figure 2 Ventilatory responses to increasing resistance to airflow produced either by external resistance $(x)$ or methacholine (O) in a single asthmatic subject. Shown from top to bottom are average inspiratory airflow (VT/TI) (liters per second), duration of inspiration (in seconds) (TI) and the duration of expiration (in seconds) (TE). $O$ indicates the control value.

change in resistance. However, the number used to quantitate the sense of effort was greater at all levels of resistance during bronchoconstriction as compared with external resistive loading. Fig. 8 shows the relationship between Sraw and the perception of respiratory effort during external resistance and methacholineinduced bronchoconstriction in one subject while Fig. 9 shows the results obtained in the entire group.

\section{DISCUSSION}

In both normal and asthmatic subjects, bronchoconstriction altered respiratory mechanics, breathing, and respiratory sensations in a significantly different manner than external resistive loading. For a given increase in resistance to airflow, bronchoconstriction increased

TABLE III

Ventilation and Pattern of Breathing at the Severest Level of Obstruction Produced by Methacholine-induced Bronchoconstriction and External Resistive Loading in Six Asthmatic Subjects

\begin{tabular}{|c|c|c|c|c|c|}
\hline & $\mathrm{VT} / \mathbf{T I}$ & TI & TE & $\mathrm{TV} / \mathrm{T}_{\text {Tot }}$ & $\dot{\mathrm{V}}_{\mathbf{E}}$ \\
\hline & liters/s & $s$ & $s$ & $\%$ & liters/min \\
\hline Control (mean $\pm 1 \mathrm{SE})$ & $0.49 \pm 0.05$ & $1.77 \pm 0.21$ & $2.56 \pm 0.38$ & $0.42 \pm 0.01$ & $12.1 \pm 0.9$ \\
\hline $\begin{array}{l}\text { Methacholine-induced bronchoconstriction } \\
(\text { mean Sraw }=38.2 \pm 6.6 \mathrm{SE})(\text { mean } \pm 1 \mathrm{SE})\end{array}$ & $0.61 \pm 0.09^{* \cdot+}$ & $1.36 \pm 0.13^{* \cdot} \ddagger$ & $2.35 \pm 0.36^{*}$ & $0.40 \pm 0.02$ & $14.3 \pm 1.6^{*,+}$ \\
\hline $\begin{array}{l}\text { External resistance }\left(13.33 \mathrm{~cm} \mathrm{H}_{2} \mathrm{O} / \text { liters per } \mathrm{s}\right. \\
\text { mean } \mathrm{Sraw}=33.3 \pm 7.3 \mathrm{SE})(\text { mean } \pm 1 \mathrm{SE})\end{array}$ & $0.48 \pm 0.05$ & $2.12 \pm 0.16$ & $2.69 \pm 0.29$ & $0.42 \pm 0.01$ & $12.3 \pm 1.1$ \\
\hline
\end{tabular}

${ }^{*} P<0.05$ for the comparison with control.

$\$ P<0.05$ for the comparison with external resistance. 

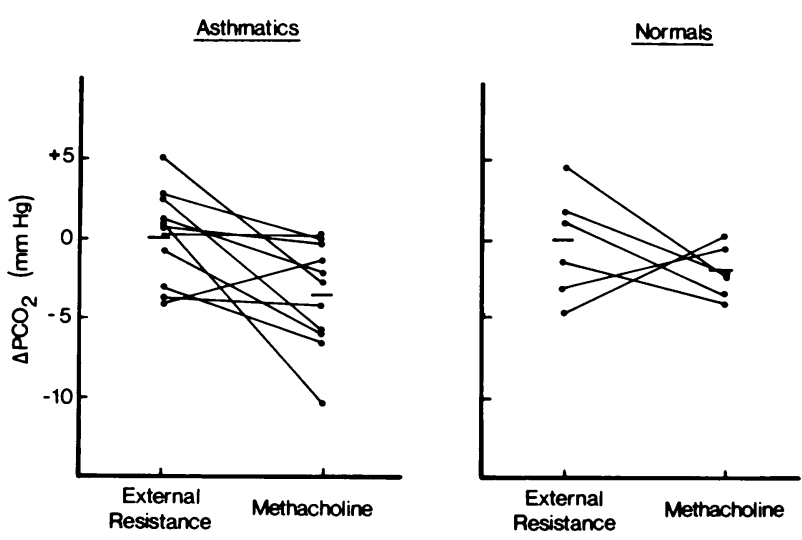

Figure 3 Change in end tidal $\mathrm{P}_{\mathrm{CO}_{2}}$ from control value during both forms of airway obstruction in each subject. Results of asthmatic and normal subjects are shown in the left and right panels, respectively. Data from individual subjects are shown connected by the line.

end-expiratory lung volume to a greater extent than did externally applied obstruction to airflow. Moreover, previous studies by others indicate that methacholine-induced airway obstruction is associated with a decrease in lung compliance (14). Similar findings were obtained in the present study when lung compliance was measured both statically and dynamically in two asthmatic subjects using the technique of Milic-Emili et al. (15). External resistive loading on the other hand had no effect in one subject and increased lung compliance in the other.

Obstruction to airflow produced by bronchoconstriction increased the frequency of breathing and the average rate of inspiratory airflow resulting in an increase in ventilation and hypocapnia. In contrast, the ex-

Asthmatic
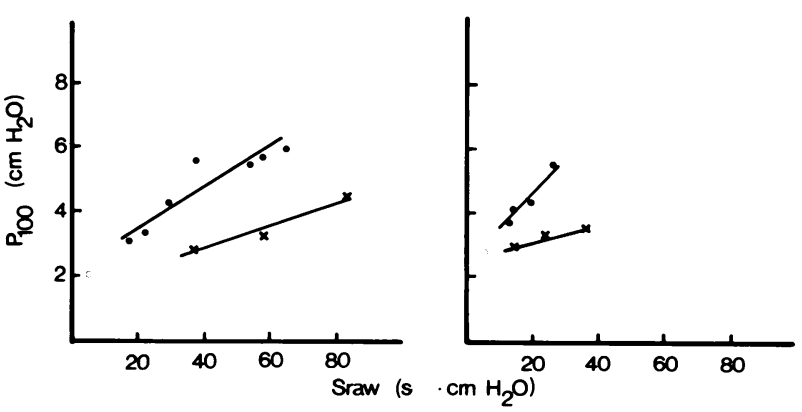

Figure 4 Occlusion pressure responses to increasing resistance to airflow obtained in a representative normal (right panel) and asthmatic subject (left panel). $\times$ indicate results obtained during external resistance; obtained during methacholine-induced bronchoconstriction. $\bigcirc$ indicate control values.
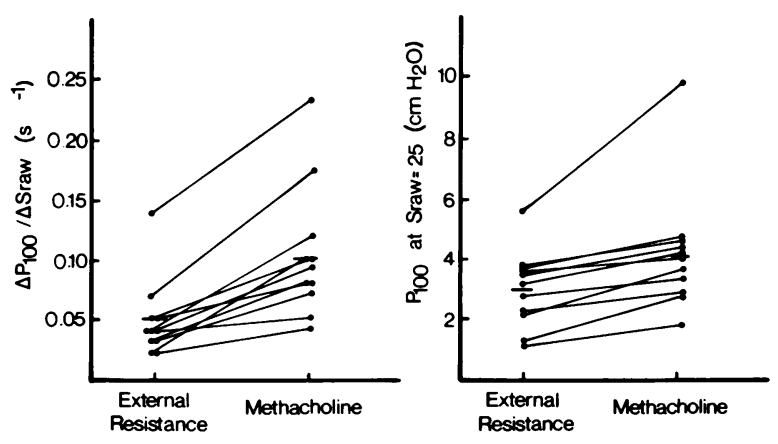

Figure 5 Occlusion pressure responses to airway obstruction in each asthmatic subject. Left panel shows the change in occlusion pressure produced by a given change in airway resistance $\left(\Delta \mathrm{P}_{100} / \Delta\right.$ Sraw $\left.\cdot S\right)$. Right panel shows the occlusion pressure at a specific resistance of $25 \mathrm{~s} \cdot \mathrm{cm} \mathrm{H}_{2} \mathrm{O}$.

ternally applied resistance slowed breathing, reduced inspiratory airflow rate, and left ventilation and $\mathrm{P}_{\mathrm{CO}_{2}}$ unchanged. The pattern of breathing during methacholine-induced bronchospasm is therefore similar to that noted in both conscious and anesthetized animals following bronchoconstriction caused by histamine or antigen aerosols (16-18). These latter two agents seem to affect breathing by stimulation of irritant receptors. However, the faster respiratory rate seen during bronchoconstriction also resembles that observed in conscious man breathing from rigid containers or during chest strapping and suggests that the response may also have been related to the decrease in lung elasticity that tends to occur with methacholine inhalation (19-21).

In both normals and asthmatics, bronchoconstriction elicited greater rises in occlusion pressure in comparison with the external flow resistive load. The greater absolute value of occlusion pressure in the asthmatics appears to be due to their heightened airway reactivity
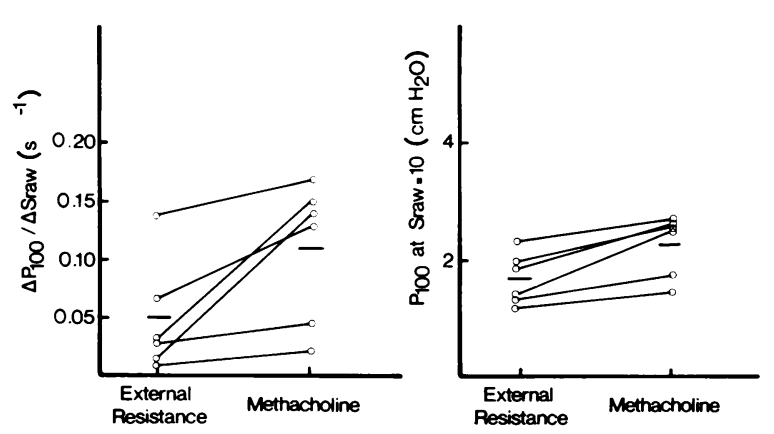

Figure 6 Occlusion pressure responses to airway obstruction in each normal subject. Left panel shows changes in occlusion pressure produced by a given change in airway resistance $\left(\Delta \mathrm{P}_{100} / \Delta\right.$ Sraw $\left.\cdot \mathrm{S}\right)$. Right panel shows the occlusion pressure at a specific resistance of $10 \mathrm{~s} \cdot \mathrm{cm} \mathrm{H}_{2} \mathrm{O}$. 


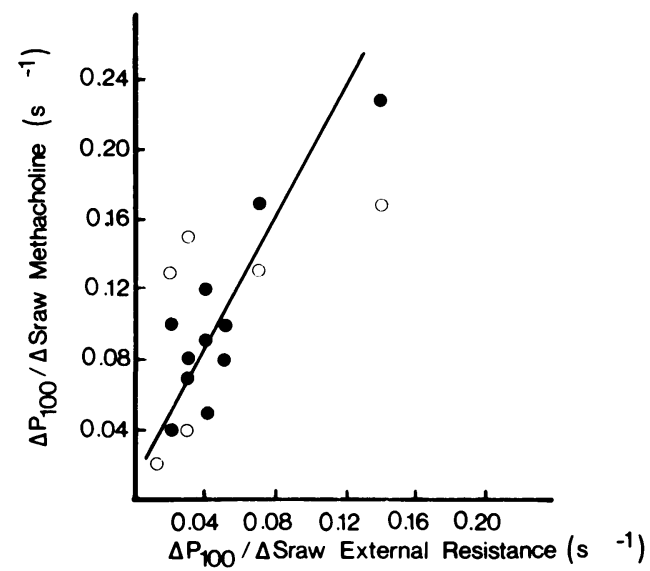

FIGURE 7 Relationship of occlusion pressure responses $\left(\Delta \mathrm{P}_{100} / \Delta \mathrm{Sraw} \cdot \mathrm{S}\right)$ to bronchoconstriction (vertical axis) and external resistance (horizontal axis). $O$ indicate data of normal subjects; that of asthmatic subjects $(r=0.77)$.

that resulted in greater increases in resistance than in the normals.

Our data suggest that the greater occlusion pressure response to bronchoconstriction is mediated by neural mechanisms rather than by alterations in chemical drive or enhanced respiratory muscle function. Specifically, decreases in end tidal $\mathrm{CO}_{2}$ observed with bronchoconstriction should have produced an effect opposite to that seen. Since the subjects were breathing $100 \% \mathrm{O}_{2}$ during the experiments, changes in hypoxic drive did not contribute to the differing responses. Finally, since increases in FRC place the inspiratory muscles at a mechanical disadvantage by decreasing their precontraction length, the pressure generating ability of the muscles should have been less during bronchoconstriction than during external flow loading $(22-24)$.

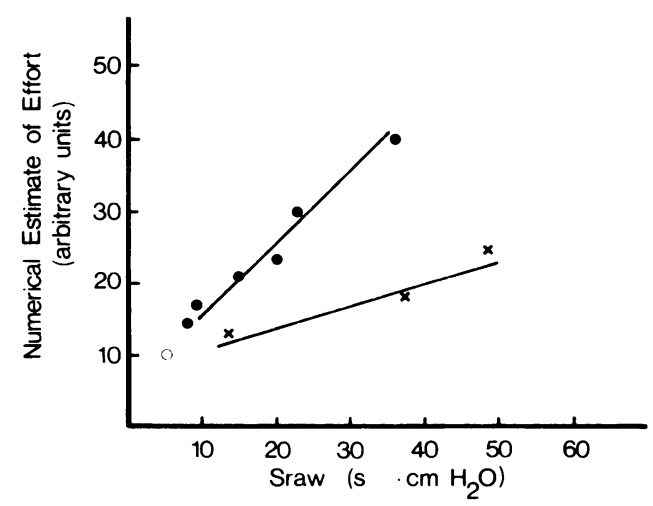

Figure 8 Sense of effort associated with breathing during increasing resistance to airflow in a single asthmatic subject. $x$ indicate data obtained during extemal resistance breathing; $\bigcirc$, datat during methacholine-induced bronchoconstriction. O indicates control value.

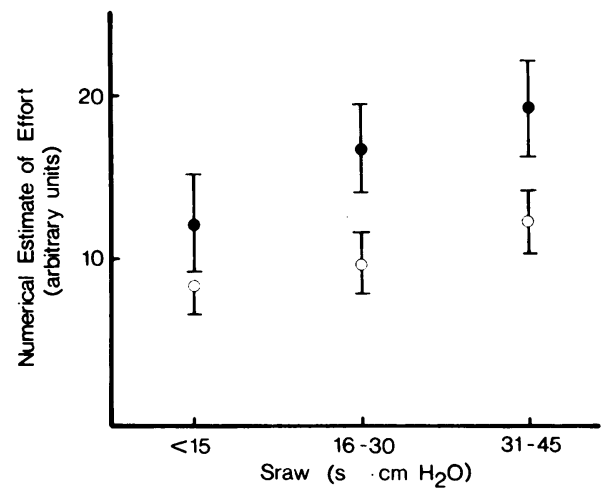

FIGURE 9 Sense of effort during increasing resistance to airflow produced by external resistance $(O)$ or methacholine administration (O) in asthmatic subjects. Results obtained at three levels of airway resistance are shown. Mean values \pm 1 $\mathrm{SE}$ are for the group as a whole.

The correlation between occlusion pressure responses to external resistances and bronchoconstriction shown in Fig. 7 suggests that the two interventions stimulate respiratory drive by closely related but not identical mechanisms. Bronchoconstriction seems to provide an additional stimulus that enhances the output to the respiratory muscles.

Two categories of mechanoreceptors may be activated by an obstruction to airflow. One group consists of the muscle spindles and tendon organs of the rib cage muscles and diaphragm that sense the length and tension developed by the respiratory muscles. The second group consists of the receptors in the airways: irritant receptors superficially located in the bronchial mucosa and stretch receptors in the bronchial smooth muscle.

An external resistance added to the respiratory system can stimulate the muscle spindles of the chest wall and trigger a reflex increase in respiratory motor activity (25). Even when methacholine-induced bronchoconstriction produces a similar change in resistance, the load sensed by receptors in the respiratory muscle may be greater because of changes in the elastic properties of the lung that accompany methacholine administration (15). Therefore, the afferent signal to the respiratory center from chest wall receptors may be more during bronchoconstriction causing a greater neuromuscular output.

Reflexes originating from irritant receptor stimulation may also contribute to the greater neuromuscular output seen with bronchoconstriction (26-28). It does not appear that irritant receptors are stimulated by addition of an extemal flow resistance to any significant degree. If anything, the reduction in airflow produced by added external resistance might decrease receptor afferent activity (29). However, methacholineinduced bronchospasm could activate irritant receptors 
in three ways: first, by the direct irritant effect of the aerosolized material on the bronchial mucosa (30). Second, increased tone of bronchial smooth muscle has been shown to activate irritant receptors (31). Finally, as bronchospasm progresses, portions of the lung may be compressed by contiguous hyperinflated regions increasing respiratory stimulation by a deflation reflex (32).

These same reflex mechanisms may also serve to explain the difference in the sensation of effort during external loading and bronchoconstriction. Although the mechanisms underlying the sensation of effort when respiratory mechanics are deranged are poorly understood, it is generally accepted that sensory information from mechanoreceptors in the lungs and/or chest wall is involved in producing the sensation (33). The greater sense of effort during bronchoconstriction could be explained by augmented spindle receptor afferent activity resulting from the change in lung elasticity. The afferent impulses from irritant receptors may also contribute to the greater sensation of labored breathing. Alternatively, however, the greater sense of effort during bronchoconstriction may reflect the conscious perception of the greater motor activity itself. It has been shown, for example, that the sense of effort present when lifting weights or performing isometric muscular contractions is not entirely explained by sensory feedback but appears to be due, at least in part, to a conscious awareness of motor command signals (34).

In this regard we compared the sense of effort produced by both forms of obstruction to air flow as a function of the magnitude of the occlusion pressure. When the occlusion pressure was $<3 \mathrm{~cm}_{2} \mathrm{O}$, the median value for the occlusion pressure, the numerical estimate of effort during bronchospasm and external loading was $12.5 \pm 3.3 \mathrm{SE}$ and $11.5 \pm 3.5 \mathrm{SE}$, respectively $(P>0.20)$. With occlusion pressure values $>3 \mathrm{~cm} \mathrm{H}_{2} \mathrm{O}$, the numerical estimate of the sense of effort during

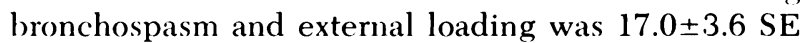
and 16.6 $\pm 3.3 \mathrm{SE}$, respectively $(P>0.20)$. These data suggest that an increase in the sense of effort may be associated with increases in occlusion pressure and that at a given value of occlusion pressure, the sense of effort during external loading and bronchospasm may be similar.

\section{ACKNOWLEDGMENTS}

This work was supported in part by National Institutes of Health grant HL-20847, a Veterans Administration grant, and an Academic Award to Dr. Kelsen.

\section{REFERENCES}

1. Kryger, M. H., O. Yacoub, and N. R. Anthonisen. 1975. Effect of inspiratory flow resistance on occlusion pressure in hypoxia and hypercapnia. Respir. Physiol. 24: 241-248.

2. Altose, M. D., S. G. Kelsen, N. N. Stanley, R. S. Levinson,
N. S. Cherniack, and A. P. Fishman. 1976. Effects of hypercapnia on mouth pressure during airway occlusion in conscious man. J. Appl. Physiol. 40: 338-351.

3. I opata, M., J. I afata, M. J. Evanitch, and R. V. Iourenco. 1977. Effects of flow resistive loading on mouth occlusion pressure during (C(), rebreathing. Am. Rev. Respir. Dis. 115: 7.3-81.

4. Altose, M. D., W. C. McCauley, S. G. Kelsen, and N. S. Cherniack. 1977. Effects of hypercapniat and inspiratory flow resistive loading on respiratory activity in chronic airways obstruction. J. (Clin. Incest. 59: 500-507.

5. Kelsen, S. G., B. Fleegler, and M. I). Altose. 1979. The respiratory neuromuscular response to hypoxia, hypercapnia, and obstruction to airflow in asthma. Am. Rev. Respir. Dis. 120: 517-527.

6. Isaza, (G. D., J. D. Posner, M. 1). Altose, S. G. Kelsen, and N. S. Chemiack. 1976. Airway orclusion pressures in awake and anesthetized goats. Respir. Physiol. 27: 87-98.

7. Lopata, M., M. J. Evanitch, and R. V. I ourenco. 1977. Relationship between mouth occlusion pressure and electrical activity of the diaphragm: effects of flow resistive loading. Am. Rev. Respir. Dis. 116: 449-455.

8. Mann, J., C. A. Bradley, and N. R. Anthonisen. 1978. Occlusion pressure in acute bronchospasm induced by methacholine. Respir. Physiol. 33: 339-347.

9. Cade, J. F., A. J. Woolcock, A. S. Reluck, and M. C. F. Pain. 1971. lung mechanics during provocation of asthma. Clin. Sci. (Oxf.) 40: 381-391.

10. Parker, C. F., R. E. Bilbo, and C. E. Reed. 1965. Methacholine aerosol as a test for bronchial asthma. Arch. Intern. Med. 115: 452-458

11. American Thoracic Society 1962. I)efinitions and classifications of chronic bronchitis, asthma, and pulmonary emphysema. Am. Rev. Respir. I)is. 85: 762-768.

12. Dubois, A. B., S. Y. Botelho, and J. H. Comroe, Jr. 1956. A new method for measuring airway resistance in man using a body plethysmograph: values in normal subjects and in patients with respiratory discase. J. Clin. Invest. 35: $327-335$.

13. Chai, H., R. S. Farr, L. A. Froehlich, D. A. Mathison, J. A. McLean, R. R. Rosenthal, A. L. Sheffer II, S. L. Spector, and R. G. Townley. 1975. Standardization of bronchial inhalation challenge procedures. J. Allergy and Clin. Immunol. 56: 32:3-327.

14. Colebatch, H. J. H., C. R. Olsen, and J. A. Nadel. 1966. Effect of histamine, serotonin, and acetylcholine on the peripheral airways. J. Appl. Physiol. 21: 217-226.

15. Milic-Emili, J., J. Mead, J. M. Turner, and E. M. Glauser. 1964. Improved technique for estimating pleural pressure from esophageal balloons. J. Appl. Physiol. 191: $207-211$

16. Karczewski, W., and J. Widdicombe. 1969. The role of the vagus nerves in the respiratory and cinculatory responses to intravenous histamine and phenyldiguanide in rabbits. J. Physiol. 201: 271-291

17. Cotton, D. J., E. R. Bleecker, S. P. Fischer, P. D. Graf, W. M. Gold, and J. A. Nadel. 1977. Rapid shallow breathing after Ascaris suum antigen inhalation: role of the vagus nerves. J. Appl. Physiol. 42: 101-106.

18. Bleecker, E. R., D. J. Cotton, S. P. Fischer, P. D. Graf, W. M. Gold, and J. A. Nadel. 1976. The mechanism of rapid shallow breathing after inhaling histamine aerosol in exercising dogs. Am. Rev. Respir. Dis. 114: 909-915.

19. Freedman, S., and S. A. Weinstein. 1965. Effects of external elastic and threshold loading on breathing in man. J. Appl. Physiol. 20: 469-472.

20. Margaria, C. E., S. Iscoe, L. I). Pengelly, J. Couture, H. Don, and J. Milic-Emili. 1973. Immediate ventilatory 
response to elastic loads and positive pressure in man. Respir. Physiol. 18: 347-369.

21. Agostoni, E., E. D’Angelo, G. Torri, and L. Ravenna. 1977. Effects of uneven elastic loads on breathing pattern of anesthetized and conscious men. Respir. Physiol. 30: 153-168.

22. Pengelly, L. D., A. M. Alderson, and J. Milic-Emili. 1971. Mechanics of the diaphragm. J. Appl. Physiol. 30: 797-805.

23. Evanitch, M. J., M. J. Franco, and R. V. Lourenco. 1973. Force output of the diaphragm as a function of phrenic nerve firing rate and lung volume. J. Appl. Physiol. 35: 208-212.

24. Eldridge, F., and K. Z. Vaugh. 1977. Relationship of thoracic volume and airway occlusion pressure: muscular effects. J. Appl. Physiol. 43(Respir. Environ. Exercise Physiol.): 312-321.

25. Shannon, R., and F. W. Zechman. 1972. The reflex and mechanical response of the inspiratory muscles to increased airflow resistance. Respir. Physiol. 16: 51-69.

26. Mills, J. E., H. Sellick, and J. G. Widdicombe. 1969. Activity of lung irritant receptors in pulmonary microembolism, anaphylaxis, and drug induced bronchoconstriction. J. Physiol. (Lond.) 203, 337-357.

27. Koller, E. G., and P. Ferrer. 1973. Discharge patterns of lung stretch receptors and activation of deflation fibers in anaphylactic bronchial asthma. Respir. Physiol. 17: 113-126.

28. Glogowska, M., P. S. Richardson, J. G. Widdicombe, and A. J. Winning. 1972. The role of the vagus nerves, periph- eral chemoreceptors, and other afferent pathways in the genesis of augmented breaths in cats and rabbits. Respir. Physiol. 26: 179-196.

29. Sellick, H., and J. G. Widdicombe. 1969. The activity of lung irritant receptors during pneumothorax, hyperpnea, and pulmonary vascular congestion. J. Physiol. (Lond.) 203: 359-381.

30. Paintal, A. S. 1973. Vagal sensory receptors and their reflex effects. Physiol. Rev. 53: 159-227.

31. Vidruk, E. H., H. L. Hahn, J. A. Nadel, and S. R. Sampson. 1977. Mechanisms by which histamine stimulates rapidly adapting receptors in dog lungs. J. Appl. Physiol. 43(Respir. Environ. Exercise Physiol.): 397-402.

32. Koller, E. A., and P. Ferrer. 1970. Studies on the role of the lung deflation reflex. Respir. Physiol. 10: 172-183.

33. Von Euler, C. 1974. On the role of proprioceptors in perception and execution of motor acts with special reference to breathing. In Loaded Breathing. L. D. Pengelly, A. S. Rebuck, and E. J. M. Campbell, editors. Longman Canada, Ltd., Ontario. 139-154.

34. McCloskey, D. I. 1978. Kinesthetic sensibility. Physiol. Rev. 58: 713-820.

35. Morris, J. F., A. Koski, and L. C. Johnson. 1971. Spirometric standards for healthy non-smoking adults. Am. Rev. Respir. Dis. 103: 57-67.

36. Boren, J. H., R. C. Kory, and J. C. Snyder. 1966. The Veterans Administration-Army cooperative study of pulmonary function II. The lung volume and its subdivisions in normal man. Am. J. Med. 41: 96-114. 